\title{
A STUDY ON THE PATTERN OF SOCIAL MEDIA USAGE DURING ISOLATION PERIOD
}

\section{KOMALPREET SINGH ${ }^{1}$, DR. TARANJIT SINGH VIJ', MANU SHARMA ${ }^{3,}$ PARMINDER KAUR ${ }^{4} \&$ DR A. K. SAIHJPAL ${ }^{5}$}

${ }^{I}$ Assistant Professor, phd Scholar at GNA University, Phagwara, Punjab,India

${ }^{2}$ Assistant Professor at GNA University, Phagwara, Punjab, India

${ }^{3}$ Assistant Professor, phd Scholar at GNA University, Phagwara, Punjab, India

${ }^{4}$ Assistant Professor, phd Scholar at GNA University, Phagwara, Punjab, India

${ }^{5}$ Research Dean, GNA University, Phagwara, Punjab, India

\begin{abstract}
Social networks have become major pieces of human lives, and their fame is expanding at an amazing rate each day. It has met an eager reaction and acknowledgment. Web-based totally lifestyles is a time period used to create the affiliation between gatherings in which society communicate their opinions. Lockdown as preventive strategies aimed to cut community transmission as a best weapon to defeat the COVID-2019. The pandemic born lockdown was clearly having an impact on the living habits of people and their social behavior. The first instance of coronavirus accounted in January 30 while the nation went into a lockdown from March 24. From that season of social confinement, remaining associated was a higher priority. Customers depended on media for wellbeing and security updates, diversion and methods for keeping up prosperity by cooperating with families and companions. Remain at home during this time; people were spending a greater amount of their lives on the web. A colossal piece of web client was assuming dynamic job on significant online life stages. Huge ubiquity in online life organizing has been giving people a superior channel to associate.

For such reasons, in this paper we proposed the survey to ascertain the activities performed by people on social media networks during lockdown. The overview led inside the time of 10 days. Surveys disseminated through Instagram, Facebook, Whatsapp and E-mail. This papers is featuring questions which presumed that internet based life is assuming a functioning job during the lockdown.
\end{abstract}

KEYWORDS: Covid-19, Lockdown, Social Networks, Web Based Life

Received: Jun 08, 2020; Accepted: Jun 28, 2020; Published: Aug 31, 2020; Paper Id.: IJMPERDJUN2020986

\section{INTRODUCTION}

At the end of March 2020 authorities of India imposed isolation restriction over the commercial activities and mass gathering including educational and public institutions. In such an exceptional situation of the century, we were living in it was crucial to understand how people were adopting to the constraints imposed on by the government due to coronavirus lock-down and its impact on given population and their routines. It was pivotal to begin research studies to deal with the likelihood of impact of the coronavirus lockdown on human life. For instance, collecting data through web-based surveys was increasingly popular (Mahendra Kumar, Sachin Dwivedi, 2020).

The online lifestyles are the networks that arise between structures of individuals. With a help of the webprimarily based existence, youngsters now traded thoughts, emotions, data, pictures and recordings. During crisis 
events, individuals routinely looked out occasion related records to remain instructed about what was happening on (Nickolas M. Jones, Rebecca R. Thompson, Christine Dunkel Schetter, and Roxane Cohen Silver, 2017). The worldwide had altered a dreadful parcel over the essential segment of 2020, with the pandemic influencing very tons all aspects of our lives. The world had changed much over the main quarter of 2020, with the COVID-19 pandemic affecting pretty much every part of our lives. These progressions had unmistakably clear on the planet's computerized practices as well, particularly as billions of people associated with gadgets to aid them with adapting to life and work under lockdown (Simon kemp, 2020). One of the clearest patterns as of late had been an emotional increment in mingling with computerized stages, regardless of whether that was with family, companions, or associates and business accomplices. During lockdown individuals got a handle on internet systems administration to the point whereby we enrolled an exceptional climb in screen time, a 25\% extension in duty on Instagram and TikTok in the earlier month and a staggering 72\% augmentation on \#ad content by influencers. (Chris Adams, 2020). This was not unexpected obviously; with such a significant number of people battling with social disengagement measures or a total lockdown, advanced stages were progressively our solitary chance to speak with the outside world.

The virus was increasing around the world. Procure information and data pandemic, various analysts began to look into in this area (Zahra Batooli, Mansour Sayyah, 2020). Today, online networking, such as, Twitter, Face book and Instagram have become essential wellsprings of data. As very little ongoing writing was accessible for investigate. Be that as it may, a few specialists had various feelings into a lot of research on the point of view of web-based life during isolate time. In this way, our examination found out the overview which finished up the utilization of person to person communication during lockdown-2020.

\section{Social Media During Lockdown}

The term Social Media alludes to the utilization of online and portable innovations to transform correspondence into an intuitive discourse. Andreas Kaplan and Michael Flaenlein characterize web based life as "a gathering of Internet-put together applications that work with respect to the ideological and mechanical establishments of Web 2.0, and that permit the creation and trade of client produced content". Web based life are media for social cooperation, as a very set past social correspondence.

The world is confronting a grand test. Times were alarming and questionable yet one of the positives to come out of this so far have been people groups' capacities and eagerness to meet up and help one another. We constantly informed that we live occupied, egotistical, and divided lives, yet the manner in which people and organizations have ventured up to enable their networks to have been nothing short incredible. Online life had a gigantic influence in that. We had seen it before in other critical circumstances yet its capacity to keep every one of us associated can't, and shouldn't be, thought little of. The lockdown made another season of constrained seclusion, and the chance of that turning into a strain on our psychological well-being is genuine. Our alternatives to associate, blend and mingle have removed (Andrew Trotman, 2020).

\section{REVIEW OF LITERATURE}

The primary examination via web-based networking went back to the $2009 \mathrm{H} 1 \mathrm{~N} 1$ pandemic, following commonness of deception wording use ("H1N1" versus "pig influenza"), open conclusions and dread, and connections between case occurrence and open concern. The WHO pronounced that they were as of now battling a universal pandemic as well as an 
online life infodemic, with certain media guaranteeing that the coronavirus is the main genuine web-based life infodemic on the grounds that it has quickened data and deception worldwide and was filling frenzy and dread among individuals ( Hao K, Basu T, 2020).

Clients of web-based life utilized the stages to communicate their feelings, sentiments, and contemplations, which can be a significant wellspring of information for exploring emotional well-being (Wongkoblap A, Vadillo MA, Curcin V., 2020). During emergency occasions, individuals frequently searched out occasion related information to remain educated regarding what was happening (Nickolas M. Jones, Rebecca R. Thompson, Christine Dunkel Schetter, and Roxane Cohen Silver, 2017). According to the consequences of an overview on the effect of the pandemic on channels utilization across India, it noticed a spike in use of person to person communication applications in the primary period of the across the country lockdown (Sanika Diwanji, 2020).

The course of the pandemic in India was distinctive as far as mortality and spread of contamination when contrasted with some different nations of the world right now. The social, monetary, and mental effect of the pandemic was perceptible We believe it's essential to investigate the ways, how individuals have found to adapt to the pandemic circumstances one side with social detachment on the opposite side that may have never-seen. It was a chance to discover how individuals were modifying their everyday practice and propensities while remaining inside their homes. There were crunches of examination in the current writing with respect to the effect of coronavirus forced lockdown on day by day, life, which may fill in extra time through the most recent exploration.

\section{RESEARCH METHODOLOGY}

The quantitative methodology adopted for this research which brought out the concept of consumption of social media during Covid-19. As not much of the literature available for this research thus to know the in-depth of the buyer mind the quantitative methodology adopted from 250 respondents.

The study surveyed teenagers, youngsters, middle-aged from middle and upper middle-class families and found that how they use social network sites. Research method based upon convenience sampling and online survey used for the validation of findings. The objective behind gathering information based on how online life assumed a functioning job during the main quarter of 2020. In this examination, a survey conducted to gather information. As per the respondents, males $(n=142)$ and females $(n=108)$ associated with this review.

\section{Objective of the Study}

This study directed to think about the job of internet based life during isolation period. So the general goal of the investigation was to discover the use of online networking during lockdown due COVID-19.

\section{Information Analysis \& Interpretation}

Part - A

Table 1: Number of reactions from the respondents

\begin{tabular}{|c|c|c|}
\hline & \multicolumn{2}{|c|}{$\mathbf{N}$} \\
\hline Opinion Poll & Present & Absent \\
\hline Which social network does you most at the time of Lockdown? & 238 & 12 \\
\hline Do you consider yourself addicted to social media during Corona Virus? & 238 & 12 \\
\hline What amount time do you spend via web-based networking media every day during lock down? & 238 & 12 \\
\hline Which type of contents do you share most during this time? & 238 & 12 \\
\hline
\end{tabular}




\begin{tabular}{|l|c|c|}
\hline Why do you mainly use social media network during lock down? & 238 & 12 \\
\hline Do you consider that social media is responsible for exploring fake news during Corona virus? & 238 & 12 \\
\hline Do you think that social media is helpful to create awareness among public during Covid-19? & 238 & 12 \\
\hline Total & 238 & 12 \\
\hline
\end{tabular}

Part- B: Cross Examination of the Respondents as Indicated by their Reactions.

\begin{tabular}{|c|c|c|c|c|c|c|c|c|c|}
\hline \multirow{3}{*}{$\begin{array}{l}\text { Which } \\
\text { network } \\
\text { do you } \\
\text { use most } \\
\text { at the } \\
\text { time of } \\
\text { Lockdow } \\
\text { n? }\end{array}$} & Types & Facebook & Instagram & Tiktok & Snapchat & Twitter & $\begin{array}{c}\text { You } \\
\text { Tube }\end{array}$ & Others & Total \\
\hline & Count & 43 & 62 & 59 & 11 & 1 & 52 & 10 & 238 \\
\hline & $\%$ age & 18.06 & 26.05 & 24.79 & 4.62 & .42 & 21.84 & 4.20 & $100 \%$ \\
\hline \multirow{3}{*}{$\begin{array}{l}\text { What } \\
\text { amount } \\
\text { time do } \\
\text { you spend } \\
\text { via web- } \\
\text { based } \\
\text { networkin } \\
\text { g media } \\
\text { every day } \\
\text { during } \\
\text { lock } \\
\text { down? }\end{array}$} & Time & $\begin{array}{l}\text { Below } 20 \\
\text { Minutes }\end{array}$ & $\begin{array}{l}\text { I hour or } \\
\text { Below an } \\
\text { hour }\end{array}$ & $\begin{array}{l}2-3 \\
\text { Hours }\end{array}$ & 3 Hours+ & & & & \\
\hline & Count & 32 & 67 & 69 & 70 & & & & 238 \\
\hline & \%age & 13.44 & 28.15 & 29 & 29.41 & & & & $100 \%$ \\
\hline \multirow{3}{*}{$\begin{array}{l}\text { Which } \\
\text { type of } \\
\text { contents } \\
\text { do you } \\
\text { share } \\
\text { most } \\
\text { during } \\
\text { this time? }\end{array}$} & Contents & News & $\begin{array}{l}\text { Status } \\
\text { Updating }\end{array}$ & Videos & Images & Others & & & \\
\hline & Count & 79 & 33 & 65 & 24 & 37 & & & 238 \\
\hline & \%age & 33.19 & 13.88 & 27.31 & 10.08 & 15.54 & & & $100 \%$ \\
\hline \multirow{3}{*}{$\begin{array}{l}\text { Why do } \\
\text { you } \\
\text { mainly } \\
\text { use social } \\
\text { media } \\
\text { during } \\
\text { lock } \\
\text { down? }\end{array}$} & Activities & $\begin{array}{l}\text { Keeping } \\
\text { in touch } \\
\text { with } \\
\text { relatives/f } \\
\text { riends }\end{array}$ & $\begin{array}{l}\text { Discoverin } \\
\text { g new } \\
\text { things }\end{array}$ & $\begin{array}{l}\text { Stayin } \\
\text { g up to } \\
\text { date } \\
\text { with } \\
\text { news }\end{array}$ & $\begin{array}{l}\text { Following } \\
\text { leaders } \\
\text { and } \\
\text { celebrities }\end{array}$ & & & & \\
\hline & Count & 99 & 67 & 57 & 15 & & & & 238 \\
\hline & \%age & 41.60 & 28.15 & 23.9 & 6.4 & & & & 100 \\
\hline
\end{tabular}

\section{Section A, B: Analysis}

The following aspect deduced from table $1 \& 2$ which explained that 250 people surveyed. Among of them 238 people responded actively. It had found that $18 \%, 26 \%$, nearly $25 \%$ and $21 \%$ of respondent's used Facebook, Instagram, TikTok and YouTube respectively. However, Twitter was less common during that period. It was noteworthy that majority of respondents were using social media.

Furthermore, the survey data showed nearly $30 \%$ of respondents spent an average of more than 3 hours while $13 \%$ of them spent less than 20 minutes on social networking sites. $70 \%$ of individuals spent more time via web-based networking media during the lockdown time frame. Likewise, most of respondents were completely approaching in 
educating us the online networking stage they utilized more during that time. Interestingly, 33\% of respondents used social media for sharing news. $27 \%$ of people shared videos and rest respondents used social network to upload images, videos and status etc. nearly $42 \%$ of people used social media to communicate with relatives rest respondents used social network for following leaders, celebrities and discovering new things, etc.

Part- C: Number of Respondents Responded of Close Ended Question

\begin{tabular}{|l|c|c|c|c|}
\hline \multicolumn{1}{|c|}{ Questions } & \multicolumn{3}{c|}{ Options } \\
\hline \multicolumn{1}{|c|}{ Yes } & No & \%es & \% No \\
\hline Do you consider yourself addicted to social media during Corona Virus? & 153 & 85 & 64.28 & 35.72 \\
\hline $\begin{array}{l}\text { Do you consider that social media is responsible for exploring fake news } \\
\text { during Corona virus? }\end{array}$ & 185 & 53 & 77.73 & 22.27 \\
\hline $\begin{array}{l}\text { Do you think that social media is helpful to create awareness among } \\
\text { public during Covid-19? }\end{array}$ & 216 & 22 & 90.75 & 9.25 \\
\hline
\end{tabular}

\section{Part C: Analysis}

This study revealed that the majority of respondents i.e. more than $64 \%$ of the respondents considered them more addicted to the social media during lockdown. However, nearly $36 \%$ of respondents disagree with this. More than $77 \%$ of respondents believe that social networking sites were responsible for spreading rumors relating rumors during lockdown. But $22 \%$ respondents did not agree that social media was not responsible for creating fake news. Furthermore, nearly $91 \%$ of respondents agreed that social media networking was helpful for creating awareness to society during lockdown. Only a few respondents i.e. $9 \%$ disagreed with this statement.

\section{CONCLUSIONS}

According to the aftereffects of a study on the effect of the coronavirus on social media utilization, it found that there was a spike in use of interpersonal interaction applications in the period of the isolation period. The examination uncovered that most of the respondents had cell phones with web and knew about the presence of online life destinations.

Our research had revealed that how social media platforms were active during lockdown period. Social media were an effective and efficient strategy to spend time during lockdown. Result indicates that social media played prominent role during the difficult time of covid-19. Eventually, social media was valuable informing public during the crisis, period. Hence, nobody can deny that within the emergence of covid-19 social media was becoming more active. Somewhat, it completely influences the lives of individuals.

\section{Limitations and Recommendations}

This investigation constrained in a few perspectives. To begin with, the time period to gather information was excessively short. Henceforth, this wasn't correct, as the segment subtleties of the respondents uncover that they are from various social layers of the general public and differ in every broad angle found all in all general public. A few discoveries assumed that a few inquiries directed can't completely evoke answers to all the parts of their reactions.

For future exploration, it might be progressively useful to quantify the social nearness other than inspiration and weight, inspecting how a mental state impacts inspirations for online networking use during crisis time. In addition, more research needed as to how social media communication is beneficial for the society. 


\section{REFERENCES}

1. Adams Chris. (2020). Social Media for Brands during Lockdown - How to Adapt to the New Normal. Retrieved from https://www.thedrum.com/opinion/2020/04/08/social-media-brands-during-lockdown-how-adapt-the-new-normal

2. Andrew Trotman. (2020). Social Media's Crucial Role in Covid-19 Lockdown. Retrieved from https://www.businesscloud.co.uk/opinion/social-medias-crucial-role-in-covid-19-lockdown

3. Given, Lisa M. (2008). “Qualitative Research Methods. Thousand Oaks, CA: Sage Publications.

4. Hao K, Basu T. (2020). the Coronavirus is the First True Social-Media Infodemic. Retrieved from https://www.technologyreview.com/s/615184/the-coronavirus-is-the-first-true-social-media-infodemic/

5. Lusk, B. (2010), “Digital Natives and Social Media Behaviors: An Overview”. The Prevention Research, 17. 3-6.

6. Mahendra Kumar, Sachin Dwivedi, (2020), "Impact of Coronavirus Imposed Lockdown on Indian Population and their Habits", International Journal of Science and Healthcare Research Vol.5; Issue: 2 88-97.

7. Nickolas M. Jones, Rebecca R. Thompson, Christine Dunkel Schetter, and Roxane Cohen Silver. (2017). Distress and Rumor Exposure on Social Media during a Campus Lockdown. Retrieved from www.pnas.org/cgi/doi/10.1073/pnas.1708518114

8. Simon Kemp. (2020). Most Important Data on Digital Audiences during Coronavirus. Retrieved from https://thenextweb.com/growthquarters/2020/04/24/report-most-important-data-on-digital-audiences-during-coronavirus/amp/

9. Sanika Diwanji. (2020). COVID-19 Impact on Weekly Time Spent Using Social Networking Apps India. Retrieved from https://www.statista.com/statistics/1114459/india-coronavirus-impact-on-weekly-usage-time-of-social-networking-apps/

10. Wongkoblap A, Vadillo MA, Curcin V. (2017), "Researching Mental Health Disorders in the Era of Social Media: Systematic Review", J Med Internet Res, 29(6).

11. Zahra Batooli, Mansour Sayyah. (2020). Measuring Social Media Attention of Scientific Research on Novel Coronavirus Disease 2019. Retrieved from https://app.dimensions.ai/ 